b2k, the timescale has been obtained from Electrical Conductivity Measurements (ECM) of the solid ice and multiparameter chemical CFA of the GRIP ice core. Beyond $10 \mathrm{kyr} b 2 k$, the timescale is based on records from the NGRIP ice core: An extended spectrum of chemical paramaters using CFA, ECM, and the light intensity curve of the recorded VS. At any depth, the dating is based on the ice core with the best available high-resolution data, and the three ice cores are tied together using unambiguous reference horizons, such as volcanic ash layers or major acidity spikes. The maximum counting error at 41 kyr b2k is 1600 years. The new timescale places the Holocene/Pleistocene transition at $11,703 \mathrm{yr}$ b2k, the onset of Greenland Interstadial 3 (GIS3) at $27.8 \mathrm{kyr}$ b2k, and the onset of GIS8 at $38.3 \mathrm{kyr}$ b2k.

\section{Outlook}

At the base of the $3090 \mathrm{~m}$ thick ice sheet, the ice is melting and when bedrock was reached in 2003, basal water flooded the lowest $45 \mathrm{~m}$ of the borehole (Dahl-Jensen et al., 2003). The reddish refrozen basal water from the sub-glacial water system in the lowest $45 \mathrm{~m}$ of the borehole was recovered by drilling in 2004 and two macroscopic plant remains were recovered from the NGRIP core. One is a wood fragment of willow (Salix) and the other is a fragment of a bud scale, probably also from willow. Also, a few tiny fragments of spruce or larch (Picea/Larix) were found, potentially representing ancient vegetation from the time of

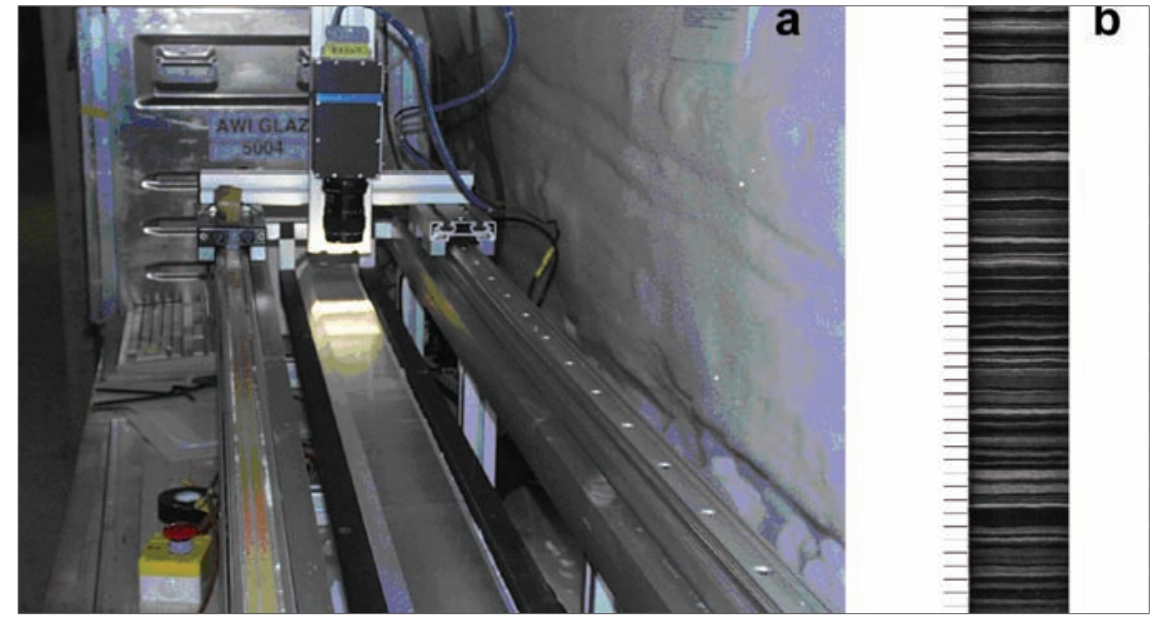

Fig. 2: As an example of the high-resolution data along the NGRIP ice core, data from the visual stratigraphy using the line scan instrument (a) is shown. A $50 \mathrm{~cm}$ long section of the record is shown in (b). The record is from $2358.0-2358.5 \mathrm{~m}$ where the age is $57 \mathrm{kyr} b 2 \mathrm{k}$ and the mean annual thickness is $1.2 \mathrm{~cm}$

the ice sheet formation. Many additional parameters like the gases, deuterium, deuterium excess, dust, as well as detailed comparisons with the Antarctic ice cores, are revealing

\section{Project facts}

Project: North Greenland Ice Core Project (NGRIP)

Contact: Dorthe Dahl Jensen, ddj@gfy.ku.dk

Participants: Numerous scientists from laboratories in 8 European nations and the USA.

Funding: Funding agencies in Denmark

(SNF), Belgium (FNRS-CFB), France (IPEV and INSU/CNRS), Germany (AWI), Iceland (Rannls), Japan (MEXT), Sweden (SPRS), Switzerland (SNF) and the USA (NSF, Office of Polar Programs)

Where: Northern Greenland

When: drilling 1996-2003, analysis ongoing.

What: $3090 \mathrm{~m}$ ice core from surface to bed-

rock, multiparameter analysis

Web page: www.glaciology.gfy.ku.dk/ngrip/ index_eng.htm

Database: www.glaciology.gfy.ku.dk/ngrip/ index_eng.htm outstanding results and will soon be published.

\section{REFERENCES}

Dahl-Jensen, D., Gundestrup, N., Gogineni, P. and Miller, H., 2003: Basal melt at NorthGRIP modeled from borehole, ice-core and radio-echo sounder observations. Annals of Glaciology, 37: 207-212.

Fischer, H., Siggard-Andersen, M.L. and Ruth U., submitted: Glacial/interglacial changes in mineral dust and sea salt records in polar ice cores: sources, transport, and deposition. Reviews of Geophysics.

North Greenland Ice-Core Project (NorthGRIP) Members, 2004: High resolution Climate Record of the Northern Hemisphere reaching into the last Glacial Interglacial Period. Nature, 431: 147-151.

Rasmussen, S. O., Andersen, K. K., Svensson, A. M., Steffensen, J. P., Vinther, B. M., Clausen, H. B., Andersen, M. -L., Johnsen, S. J., Larsen, L. B., Bigler, M., Röthlisberger, R., Fischer, H., Goto-Azuma, K., ice core chronology for the last glacial termination, Journal of geophysical research. in press.

Svensson, A., Wedel Nielsen, S., Kipfstuhl, S., Johnson, S.J., Peder Steffensden, J.P., Bigler, M., Ruth, U. and Röthlisberger, R., 2005: Visual stratigraphy of the North Greenland Ice Core Project (NorthGRIP) ice core during the last glacial period. Journal of Geophysical Research 110, D02108, doi:10.1029/ 2004JD005134. Hansson, M. E. and Ruth, U., 2005: A new Greenland

\title{
Paleoenvironmental reconstruction from Alpine ice cores
}

MARGIT ScHWIKoWSKI

Paul Scherrer Institute, Villigen, Switzerland; margit.schwikowski@psi.ch

\section{Introduction}

The European Alps, located in South-Central Europe, extend 800 $\mathrm{km}$ in the west-east and 150-200 $\mathrm{km}$ in the north-south direction (44$\left.48^{\circ} \mathrm{N}, 5.5-16^{\circ} \mathrm{E}\right)$. They form a great arc from the Riviera coast on the Mediterranean Sea, along the borders of northern Italy and adjacent regions of southeast France, Switzerland, southwest Germany and
Austria, into Slovenia. The total number of glaciers is 5422, covering an area of $3010 \mathrm{~km}^{2}$ (Paul et al., 2004). Glaciers with sufficiently cold firn temperatures, where melt-water percolation is negligible and which are therefore suitable for ice core studies, can be found above $4000 \mathrm{~m}$ asl in the northern part and above $4300 \mathrm{~m}$ asl in the southern part of the Alps (Suter et al., 2001). Thus, potential ice core sites are limited to a few high-elevation areas, such as the Bernese Alps, and the Monte Rosa and Mont Blanc areas.

The Alps are especially interesting for ice core studies because a dense network of instrumental meteorological measurements is available there and in the surrounding countries. The existence of such exclusive data sets is a ma- 


\section{Science Highlights: Ice Core Science}

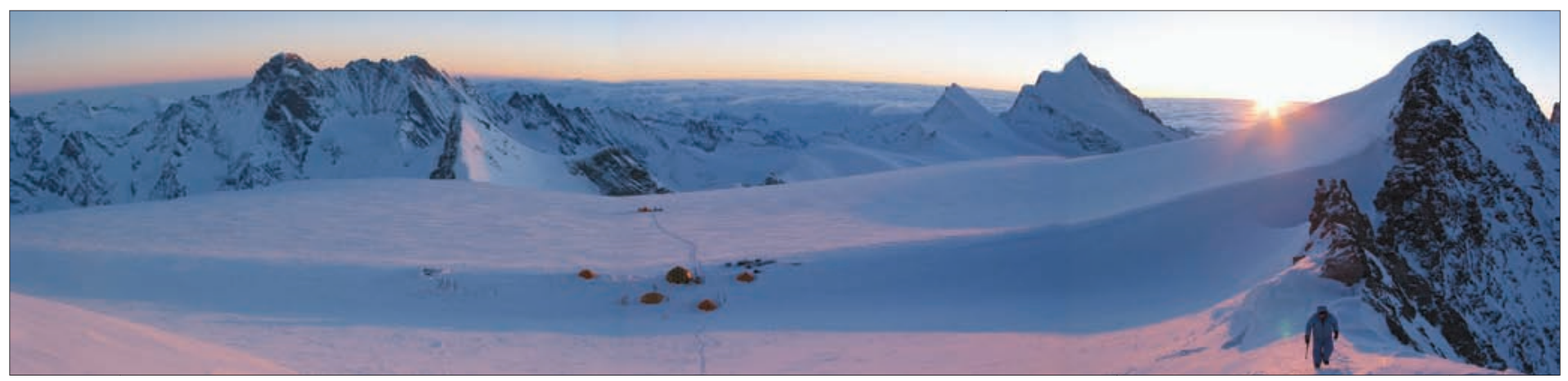

Fig. 1: Ice core drilling camp on Fiescherhorn glacier, Swiss Alps, in December 2002. (Photo A. Schwerzmann)

jor advantage compared to other ice core sites, since the ice core climate proxy records can be calibrated. This is extremely important for an improved understanding of the characteristics of the glacier archives. Some of the instrumental records reach back over 250 years (Böhm et al., 2001). Not only temperature data but also precipitation data are available and, furthermore, historical air quality measurements exist.

\section{Drill sites}

Mean annual precipitation in the Alps varies between 500 and 3000 $\mathrm{mm}$. Accordingly, relatively high annual net accumulation rates were observed at most of the ice core sites, i.e. $\sim 1.3 \mathrm{~m}$ water equivalent (weq) at Fiescherhorn glacier (Fig. 1), Bernese Alps, $1.5 \mathrm{~m}$ weq at Col du Dôme, Mont Blanc, 1.6 m weq at Lys Glacier, $2.7 \mathrm{~m}$ weq at Grenzgletscher, both Monte Rosa area, and $2.6 \mathrm{~m}$ weq at Piz Zupó, Bernina area. With typical glacier thicknesses of 80 to $150 \mathrm{~m}$ in the accumulation areas, ice core records from these sites cover rather short time periods of, at best, a few hundred years. A noteworthy exception is the Colle Gnifetti glacier saddle in the Monte Rosa area on the border between Switzerland and Italy. Due to the preferential wind erosion of dry winter snow the annual snow accumulation is in the order of only $30 \mathrm{~cm}$ weq, implying preservation of potentially more than the last 1000 years at reasonable time resolution. Indeed, 3D glaciological flow models indicate that the ice close to bedrock is more than 2000 years old (Lüthi and Funk, 2000). Here, a dramatic decrease of $\delta^{18} \mathrm{O}$ values (Wagenbach, 1994) suggests that the basal layer may be made up of Pleistocene ice. However, the $\delta^{18} \mathrm{O}$ values of $\mathrm{O}_{2}$ entrapped in air bubbles are not as high to unequivocally confirm this hypothesis (M. Leuenberger, personal communication).

\section{Results}

An important aspect of Alpine ice cores is their proximity to emission sources of anthropogenic pollution. Especially for aerosol particles and related gaseous species, with short atmospheric lifetimes, changes in the atmospheric load due to human activities and their possible impact on climate are most pronounced in industrialized areas. Detailed studies have been conducted on atmospheric transport from the emission source areas to the high altitudes, where the glacier archives are located. They show that the highaltitude aerosol concentration, and subsequently also the concentration of aerosol constituents in snow and ice, is mainly controlled by the seasonally varying intensity in vertical mixing (see e.g. Baltensperger et al., 1997). Therefore, the seasonal am-

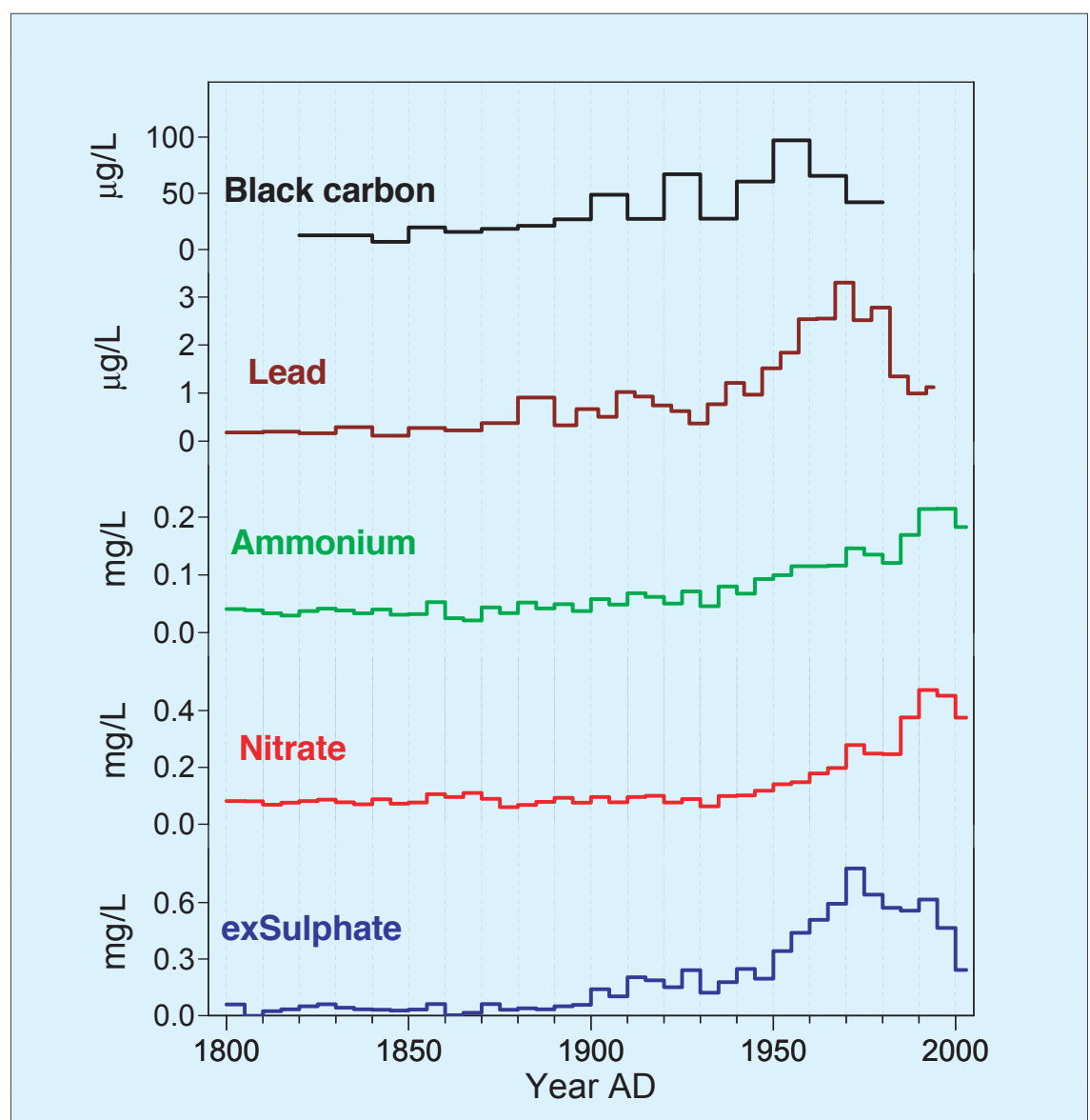

Fig. 2: Concentration trends of ex-sulphate, nitrate, ammonium, lead, and black carbon in ice cores from Colle Gnifetti, Swiss Alps. Ex-sulphate represents sulphate corrected for the sea-salt and mineral dust contribution and is assumed to originate exclusively from oxidation of sulphur dioxide in the atmosphere. Given are 5-year averages lone 4-year average for 2000-2003; composite records from cores drilled in 1982 and 2003), except for lead (10-year averages from 1800-1900, composite record from cores drilled in 1982 and 1995 (Schwikowski et al, 2004)) and black carbon (10-year averages, from a core drilled in 1982 (Lavanchy et al., 1999)). 
plitudes of aerosol concentrations are large compared to their longterm trends. This also applies to the temperature reflected in the stable isotope ratios in precipitation.

Various concentration records of a number of chemical trace species and gases obtained from the different Alpine ice cores have been published. These records clearly demonstrate the impact of anthropogenic emissions on the impurity content of snow. They show a generally consistent picture of a vastly altered atmospheric composition due to industrialization. This is the case for major aerosol components such as sulphate, nitrate, ammonium, and carbonaceous particles as well as trace substances, for example, heavy metals, fluoride, chloride, and radionuclides. Furthermore, the presence of organochlorine pesticides in Alpine ice has been shown (Villa et al., 2003). Most of the pollutants have a concentration maximum in the 1970s and early 1980s, and responded to air pollution control measures in Europe (such as introduction of filters, catalytic converters, unleaded fuel) with a downward trend in concentration, as illustrated in Figure 2 with the examples of sulphate, lead, and black carbon. Notable exceptions are nitrate (see e.g. Preunkert et al., 2003) and ammonium, which are still at a high level. In the case of nitrate, reduction of $\mathrm{NO}_{x}$ emissions in individual cars has been counterbalanced by increasing traffic. Ammonium originates from agricultural activities, such as animal manure and fertilizer application, where no control measures have been introduced.

Ice core derived concentration records of aerosol species have been used to estimate the aerosol effect on climate. For this purpose, records from mid-latitude glaciers are extremely important. On the one hand because only few long-term records of tropospheric aerosols exist, and on the other hand because data from the emission source areas are needed due to the regional nature of aerosol concentrations. Sulphate concentrations in ice cores from the Alps display the strongest anthropogenic influence during the last

\section{Project facts}

CARBOSOL - Present and Retrospective State of Organic versus Inorganic Aerosol over Europe: Implications for climate (long term ice core records of organic aerosol species)

Contact: Michel Legrand mimi@Igge.obs.ujf-grenoble.fr

Participants: LGGE-Grenoble, IUP Heidelberg

Funding: European Community coordinator: Michel Legrand

When: 2002-2005

Web page: www.vein.hu/CARBOSOL/

ALPCLIM - Environmental and Climatic Records from High Elevation Alpine Glaciers, (glacio-chemical and stable isotope studies at Monte Rosa and Mt.Blanc)

Contact: Susanne Preunkert, ps@Igge.obs.ujf-grenoble.fr

Participants: LGGE-Grenoble,University Zürich,VAW/ETH-Zürich, KUP-University Bern, DISAT-Milano, IUP Heidelberg

Funding: European Community coordinator: Dietmar Wagenbach

When:1997-2001

Web page: www.geo.unizh.ch/ hoelzle/

ALP-IMP - Multi-Centennial Climate Variability in the Alps based on Instrumental Data, Model simulations and Proxy Data (stable isotope studies on deep Monte Rosa and Mt. Blanc cores)

Contact: Dietmar Wagenbach, Dietmar.Wagenbach@iup.uni-heidelberg.de Participants: University Zürich,LSCE- Saclay, IUP Heidelberg

150 years, with a concentration increase by a factor of 13 between the pre-industrial and industrial period. The level in the Alps in the period of maximum industrial emissions is about a factor of five higher than in Greenland ice cores, whereas in Antarctica no anthropogenic sulphate could be detected (Cole-Dai et al., 2000).

\section{REFERENCES}

Böhm, R., Auer, I., Brunetti, M., Maugeri, M., Nanni، T. and Schöner, W., 2001: Regional temperature variability in the European Alps: 1760-1998 from homogenized instrumental time series, Int. J. Clim., 21 (14): 1779-1801.

Lüthi, M., and Funk, M., 2000: Dating ice cores from a high Alpine glacier with a flow model for cold firn, Annals of Glaciology, 31: 69-79.

Paul, F., Kaab, A., Maisch, M., Kellenberger, T. and Haeberli, W., 2004: Rapid disintegration of Alpine glaciers observed with satellite data, Geophys. Res. Lett., 31 (21), L21402, doi:10.1029/ 2004GL020816,

Preunkert, S., Wagenbach, D., and Legrand, M. 2003: A seasonally resolved alpine ice core record
Funding: European Community, coordinator: Reinhard Böhm

When: 2002-2006

Web page: www.zamg.ac.at/ALP-IMP

Klimageschichte im Alpenraum - aus Analysen von Eisbohrkernen

Contact: H.W. Gäggeler, heinz.gaeggeler@psi.ch

Participants: Paul Scherrer Institut and KUP Funding: Swiss National Science Foundation When: 1993-1996

VITA - Varves, Ice cores, and Tree rings - Archives with annual resolution

Contact: Margit Schwikowski, margit.schwikowski@psi.ch

Participants: Paul Scherrer Institut, University of Bern

Funding: Swiss National Science Foundation (in the frame of the NCCR Climate Program)

When: 2002-2005

Web page: www.nccr-climate.unibe.ch/

VIVALDI - Variability in Ice, Vegetation and Lake Deposits - Integrated

Contact: Margit Schwikowski, margit.schwikowski@psi.ch

Participants: University of Bern, Paul Scherrer Institut, EAWAG

Funding: Swiss National Science Foundation (in the frame of the NCCR Climatep pogram)

When: 2005-present

Web page: www.nccr-climate.unibe.ch/ of nitrate: Comparison with anthropogenic inventories and estimation of preindustrial emissions of NO in Europe, J. Geophys. Res., 108 (D21): 4681 Schwikowski, I., Barbante, C., Doering, T., Gäggeler H.W., Boutron, C., Schotterer, U, Tobler, L., Van De Velde, K.V., Ferrari, C., Cozzi, G., Rosman, K. and Cescon, P., 2004: Post-17th-century changes of European lead emissions recorded in high-altitude alpine snow and ice, Environ. Sci. Tech., 38 (4): 957-964.

Villa, S., Vighi, M., Maggi, V., Finizio, A. and Bolzacchini, E., 2003: Historical trends of organochlorine pesticides in an Alpine glacier, J. Atmos. Chem., 46 (3): 295-311.

Wagenbach, D., 1994: Results from the Colle Gnifetti ice-core programme, in: ESF/EPL Workshop on Greenhouse gases, isotopes and trace elements in glaciers as climatic evidence of the Holocene, edited by W. Haeberli, Stauffer, B., VAW Arbeitsheft. 19-22, Zürich.

For full references please consult: www.pages-igbp.org/products/newsletters/ref2006_1.html 